\title{
Analysis of Evaluation and Exploratory Studies on Student's Resilience of Online Learning during Pandemic of Covid-19
}

\author{
Adi Dewantoro', Indriyana Rachmawati² \\ ${ }^{1}$ Universitas Sebelas Maret, Surakarta Indonesia, ${ }^{2}$ Universitas Negeri Malang, Indonesia \\ adi_dewantoro@staff.uns.ac.id
}

Submitted: 2020-09-17, Revised: 2020-11-05, Accepted: 2020-11-27

\begin{abstract}
The Covid-19 pandemic has changed all systems of life, including those in the field of education. Online learning during a pandemic requires lecturers and students to learn new things that were never thought of before. Mastering technology and managing self-defence against various pressures during a pandemic are important for everyone to master. This study aims to measure the level of student resilience to online learning during the Covid-19 pandemic. This survey was conducted by distributing resilience instruments in the form of google form to students throughout the island of Java, with a total of 483 students as respondents. As many as 483 respondents who filled out the student resilience questionnaire against the Covid-19 outbreak showed that 112 respondents responded positively to online learning during the Covid-19 pandemic. Meanwhile, 371 respondents stated a negative response to online learning during the Covid-19 pandemic. Although the use of online learning models will continue with the times, it is hoped that the management of technology, pedagogy, and content in online learning can work together and provide students comfort in learning.
\end{abstract}

Keywords: Covid-19; Online Learning; Resilience.

(C) 2020 KONSELI: Jurnal Bimbingan dan Konseling (E-Journal)

\section{Introduction}

The outbreak of Corona disease caused by the Covid-19 virus in Indonesia since early March 2020 has had an extraordinary impact on all aspects of life. The spread of the coronavirus initially had a major impact on the sluggish economy, but the world of education is now felting the impact. Based on data obtained from UNESCO, currently, a total of 39 countries have implemented school closures with a total number of students reaching $421,388,462$ children. China has the highest number of students by far. Due to the coronavirus, there are about more than 233 million students (Arifudin, 2020).

Another survey result explains that nearly $80 \%$ of the world's student population of around 1.3 billion children and adolescents are affected by school closures in 138 countries (Chang \& Yano, 2020). Efforts to close schools to stop the spread of the covid -19 virus are an unprecedented challenge for the government, so the government needs to learn about the continuity of learning for school students and university students.

The policies taken by many countries, including Indonesia, by closing all educational activities, have made the government and related institutions have to present educational alternatives for students and students who cannot carry out the educational process at educational institutions. Currently in Indonesia, several campuses have begun implementing policies for teaching and learning activities from a distance or online lectures using various platforms such as Spada, Zoom Meeting, Google Meet, Google Classroom, Skype, and Whatsapp (Wargadinata, Maimunah, Febriani, \& Humaira, 2020).

Online learning is being implemented in various ways by educators amid the closure of schools and campuses during the Covid-19 pandemic. However, the implementation is considered not optimal and shows that there is still unpreparedness among educators and students to adapt to the digital climate. So far, some many schools and colleges apply online assignment methods for students. The Indonesian Child Protection Commission released a report on 213 student complaints regarding the implementation of the home learning program 
(Ernes, 2020). The majority of students complained about the heavy workload they had to do while studying at home. Learning which should have been sharing information, exploring ideas with each other, discussing with each other between teachers and students or lecturers and students, has now turned into learning using the assignment method alone. Every task must be done perfectly. The assignment is carried out through various available platforms, such as Spada, google classroom and WhatsApp. An emergency condition due to the current coronavirus, it is this form of assignment that is considered effective in distance learning. Consequently, the introduction of the concept of a lesson as applied to face-to-face learning cannot work well.

Based on the results of the initial survey conducted by researchers to students at Sebelas Maret University Surakarta in April 2020, it showed that around 69\% of respondents said that they complained about the number of assignments given by lecturers. The assignment given by the lecturer has an impact on the individual's ability to learn to understand the material and the completion of coursework. Often many students complain about a load of lecturing with an online model. Not to mention the technical constraints related to the internet connection which often become an obstacle for students in various regions in Indonesia, especially in areas that are remote and have not yet reached an internet connection. The convenience of learning with the online system is also a lot of complaints from students; they find it easier to understand the material delivered by lecturers offline than online learning. This condition requires students to have a high level of resilience related to online learning during the lockdown period for the spread of the Covid-19 virus. The times and conditions at this time require individuals to have high resilience so that individuals can carry out their daily lives (Beale, 2020).

Resilience is seen as an individual's ability to adapt to stressful changes and events healthily and flexibly (Goldstein, 2018; Hinduja \& Patchin, 2017). Students as education subjects inevitably have to adjust to changes in learning conditions which initially are conventional, leading to online/online learning. This change causes stress for students, especially the workload, which makes students frustrated and stressed. For those who have a high level of resilience or resistance to changes in learning methods, it is not a big problem; it's just that the condition of each student cannot be equalized.

Given the pressure to change learning to online systems, we can find out how dangerous it is if we cannot survive or cope with the condition. Therefore, there are many studies related to resilience that try to understand why some individuals can survive and even thrive in the stress they experience in their lives. Resilience or resilience as a general concept involves interactions between individuals, personality traits, past experiences, family and community resources (Azzahra \& Paramita, 2019; Cocoradă \& Orzea, 2017).

Based on the conditions of learning changes that occurred in the midst of the Covid-19 pandemic, researchers want to discuss the description of the level of student resilience to online learning amid the Covid-19 outbreak. The benefits of this research are expected to add insight into the conditions of online learning and the level of resilience during the Covid-19 pandemic among students, besides that it can also be used as a reference for future researchers.

Conceptually online learning is learning that is carried out without doing face-to-face through existing platforms. In the era of technological advances, many digital platforms can be used to support online learning, such as Spada, google classroom, zoom, google meet, and WhatsApp. The online learning approach has the characteristics of 1) requiring learners to build and create knowledge independently (constructivism); 2) learners will collaborate with other learners in building their knowledge and solving problems together (social constructivism); 3) forming an inclusive community of learners; 4) utilizing a web page (website) that can be accessed via the internet, computer-based learning, virtual classes and/or digital classes; 5) Interactivity, independence, accessibility, and enrichment (Djaja, 2017). 
Students' views on online learning are a new method and are not yet used in Indonesian universities. The advantage of using online learning is that learning can be done anywhere, although not always at any time. Students are not free to ask questions when learning online (Rahmatih \& Fauzi, 2020). Then in online learning on teaching materials, students must be more active in looking for their own material to increase their knowledge because during lectures, many students do not understand what the lecturer said. (Yuliani et al., 2020).

This causes students who carry out online learning to carry out the learning process in places they like while doing other things besides studying, such as eating, listening to music and watching television. For some students, online learning environments are more suitable for them than offline learning or face-to-face learning. Apart from the problem of purchasing quotas, students who use WiFi networks feel that online learning can save costs that are usually spent on a daily basis. With online learning, students no longer need to pay to go to campus in the morning.

The use of online learning during the Covid-19 pandemic should be directed at efforts to increase student absorption of the material being taught, increase student active participation, improve student self-study skills, and improve the quality of teaching and training materials (Suherman, Dewi, \& Ahmad, 2019). Other research also explains that online learning can encourage students' ability to display information with information technology devices, with ordinary devices difficult to do (Muhammad, Murtinugraha, \& Musalamah, 2020; Saugi, 2018). Referring to these efforts, it is hoped that the online learning process can run effectively, develop creativity and be fun for students. So that later students can show maximum performance in learning even though it is done online, which leads to achieving a level of resilience.

Resilience is considered as a person's ability to cope with and adapt to serious events or problems that occur in life (Reivich \& Shatté, 2002). Resilience is seen as a universal capacity; by using this capacity, individuals can prevent influences that could damage a person's condition when faced with certain problems or pressures. The same thing was also expressed by Wolff, who views resilience as a trait, this trait is a hidden capacity that appears to fight individual destruction and protect individuals from all obstacles in life (Banaag, 2002).

Resilience describes 3 phenomena, namely: 1) cognitive development produced by children living in high-risk contexts, such as poverty, violence. 2) the ability that may arise under prolonged stress, such as divorce, stress from learning stress 3) healing from trauma (Mustika \& Syukur, 2019). The three conditions or phenomena of resilience cannot be separated from the aspects forming resilience which include emotional regulation, impulse control, optimism, causal analysis, empathy, self-efficacy, and achievement (Reivich \& Shatté, 2002). So that in this study, the researchers were interested in describing the resilience of students in taking online lectures during the Covid-19 pandemic.

\section{Methods}

The method used in this study used a survey to describe and analyze the level of student resistance to learning during the Covid-19 pandemic. This study took a random sample (purposive random sampling) of 483 students from various regions throughout the island of Java using a student resilience questionnaire to the covid-19 outbreak, which was distributed via a google form. The data instrument in the survey research used a student resilience questionnaire to the Covid-19 outbreak, which was distributed via Google Form. The questionnaire consists of 74 items with alternative answers "Strongly Agree" with point 5, "Agree" with point 4, "Doubt" with point 3, "Disagree" with point 2, and "Strongly Disagree" with point 1 Apart from using a scale format with five alternative answer choices, this questionnaire also has three statements to be answered openly. The data analysis used is a descriptive analysis which describes the level of student resilience. 


\section{Results and Discussion}

Based on the results of the questionnaire data analysis of student resistance to online learning in the midst of the Covid-19 outbreak, the results are obtained in the following table:

Table 1. Survey Results of Student Resilience Levels to Online Learning during Covid-19

\begin{tabular}{|c|c|c|c|c|}
\hline \multicolumn{5}{|c|}{ Student Resilience Levels to Online Learning during Covid-19 } \\
\hline \multirow{2}{*}{ No } & \multicolumn{2}{|c|}{ Positive Response / High Resilience } & \multicolumn{2}{|l|}{ Negative Response / Low Resilience } \\
\hline & Statement & Amount & Statement & Amount \\
\hline 1 & $\begin{array}{l}\text { Online learning is very } \\
\text { interactive. }\end{array}$ & 11 & $\begin{array}{l}\text { Complaining about a large amount of } \\
\text { workload }\end{array}$ & 163 \\
\hline 2 & $\begin{array}{l}\text { Online activities in the } \\
\text { content of the discussion } \\
\text { material }\end{array}$ & 8 & $\begin{array}{l}\text { Complained about the difficulty } \\
\text { understanding the material }\end{array}$ & 45 \\
\hline 3 & $\begin{array}{l}\text { Online learning is used thesis } \\
\text { guidance and thesis proposal. }\end{array}$ & 6 & prefer conventional learning to be bold & 18 \\
\hline 4 & $\begin{array}{l}\text { Online learning is fun and } \\
\text { flexible. }\end{array}$ & 39 & Learning cannot be less varied & 8 \\
\hline 5 & $\begin{array}{l}\text { Online learning is useful for } \\
\text { avoiding the coronavirus. }\end{array}$ & 21 & $\begin{array}{l}\text { Feeling that the implementation of courage } \\
\text { is less effective and complicated }\end{array}$ & 58 \\
\hline 6 & $\begin{array}{l}\text { Learning is very effective } \\
\text { and efficient. }\end{array}$ & 21 & Lack of daring mastery of the platform & 9 \\
\hline 7 & $\begin{array}{l}\text { Learn to use and utilize } \\
\text { online learning platforms }\end{array}$ & 6 & Learning makes you lazy & 4 \\
\hline 8 & - & & Online learning is common & 35 \\
\hline 9 & - & & Bold learning is stressful & 31 \\
\hline & Amount & 112 & & 371 \\
\hline
\end{tabular}

Based on the data in the table above, it can be concluded that of the 483 respondents who filled out the questionnaire on student resilience against the Covid-19 outbreak, 112 respondents responded positively to online learning during the Covid-19 pandemic. A total of 371 respondents expressed a negative response to online learning during the Covid-19 pandemic. The number of respondents showed a positive response to online learning as many as 39 people who stated that online learning was enjoyable and flexible. As many as 21 people stated that online learning was very effective and efficient. This condition seems counterproductive with a negative response shown by 163 respondents who complained about the large number of assignments given by lecturers, 45 respondents said it was difficult to understand the material provided by lecturers during online learning and 58 respondents stated that online learning was deemed ineffective and seemed complicated in its implementation.

Research on assessment analysis and exploratory study of student resilience towards online learning in the midst of the Covid-19 outbreak begins with a survey using a questionnaire. The results of the analysis of 483 respondents' answers showed that $23.1 \%$ of around 112 respondents stated a positive response to online learning, it can be concluded that they have a high level of resilience to online learning. Meanwhile, $76.9 \%$ or around 371 respondents stated a negative response to online learning during the Covid-19 pandemic, assuming they have a low level of resilience. The results of this study are supported by other research which explains that as many as $47 \%$ of students who became the research sample said that online learning was effective and the remaining 53\% stated negative (Rusdiana \& Nugroho, 2020).

In terms of gender, there is a comparison of the level of resilience between men and women. Of the 483 respondents consisting of 103 men and 380 women, it was shown that $71 \%$ 
of the 103 male respondents showed a high level of resilience to online learning and the rest showed a low level of resilience. Meanwhile, $57 \%$ of the 380 female respondents showed a high level of resilience to online learning, and the rest had a low level of resilience. The results of this study are supported by research showing that the level of resilience of male students is higher than female students (Amelia, Asni, \& Chairilsyah, 2014; Jordan et al., 2020; Neufeld, Mossière, \& Malin, 2020).

Based on the description of the research results, it shows that online learning has many shortcomings in various aspects. Unfortunately, the shortcomings experienced by students regarding online learning are significant and can hinder the who le teaching and learning process. Starting from signal problems to difficult to focus, online learning is considered to add to the burden on students. This is reinforced by the results of research which explain that the success of online learning without strict supervision is meagre, there is no class interaction, so it is not clear the success of the learning process (Hiranrithikorn, 2019). The difficulty in understanding the material presented by lecturers to lecturers who have never provided lecture material either by video message or video conference is also considered to be a burden for students in undergoing online learning.

Students' views of online learning are not an effective learning method. Other research also explains that hands-on classroom learning can provide better learning outcomes for students at the university level than online learning (Hoult, Peel, \& Duffield, 2020). This can be seen from the complaints of students who are overwhelmed with online assignments instead of lectures to discuss a material by the lecturer. The workload of students in online lectures increases due to the higher time, costs and fatigue levels than in face-to-face lectures (Didin, Mardiono, \& Yanuarso, 2020).

As a result of the high workload, many students feel frustrated and stressed by a large number of online recovery workloads. However, online learning has several positives; the positives that online learning has no impact on the effectiveness of existing teaching and learning activities. The positive side that exists in online learning is mostly the positive side in terms of student lifestyle and student finances (Daheri, Juliana, Deriwanto, \& Amda, 2020). In contrast to the positive side, the negative side that online learning has is a weakness that can greatly affect teaching and learning activities carried out by lecturers and students, causing online learning to be an ineffective learning method.

The shortcomings of online learning are almost found in all learning; lecturers should be able to overcome this problem by conducting research and surveying the types of platforms that are most effectively used. The existence of an evaluation on each platform used will help overcome the ineffectiveness of online learning and minimize the obscurity of the learning process.

\section{Conclusions and Suggestions}

Several changes can be applied to make online learning a more effective learning method, such as lecturers who should hold video conferences so that the teaching and learning process can take place in two directions and give students the flexibility to ask questions. Lecturers explain the material they will convey to students via video or video conference media and not only giving powerpoints but limiting the number of assignments given so as not to become a burden for students. Equal distribution of signals by telecommunication companies to ensure the availability of signals when the learning process is taking place and the creation of a suitable learning platform is also adequate for all universities in Indonesia.

It is better if online learning can be further reviewed by the relevant agencies so that it becomes a more effective learning method in the future, both for students and lecturers. Although the use of online learning models will continue with the times, it is hoped that 
students will still be comfortable learning and understanding the material provided by the lecturers. To support success, online learning seems to need a formula that can combine elements of technology, pedagogy and content that synergize in the learning process carried out by lecturers and students.

\section{References}

Amelia, S., Asni, E., \& Chairilsyah, D. (2014). Gambaran ketangguhan diri (resiliensi) pada mahasiswa tahun pertama fakultas kedokteran universitas riau. Riau University.

Arifudin, O. (2020). Pandemi Corona dan Dampak Terhadap Dunia Pendidikan. Subang, Jawa Barat, Subang.

Azzahra, F., \& Paramita, R. W. (2019). The Effect of Resilience toward Psychological Distress Among Female Medical Students. In 4th ASEAN Conference on Psychology, Counselling, and Humanities (ACPCH 2018). Atlantis Press.

Banaag, C. G. (2002). Resiliency, street children, and substance abuse prevention. Prevention Preventif, 3.

Beale, J. (2020). Academic Resilience and its Importance in Education after Covid-19. Eton Journal for Innovation and Research in Education, (Issue 4), 1-6.

Chang, G.-C., \& Yano, S. (2020). How are countries addressing the Covid-19 challenges in education? A snapshot of policy measures. World Education Blog. Https://Gemreportunesco. Wordpress. Com/2020/03/24/How-Are-Countriesaddressingthe-Covid-19-Challenges-in-Education-a-Snapshot-of-Policy-Measures.

Cocoradă, E., \& Orzea, I. E. (2017). Relationships between wellbeing, resilience and school climate. Bulletin of the Transilvania University of Brasov. Series VII, Social Sciences and Law., 10(2), 191-200.

Daheri, M., Juliana, J., Deriwanto, D., \& Amda, A. D. (2020). Efektifitas whatsapp sebagai media belajar daring. Jurnal Basicedu, 4(4), 775-783.

Didin, F. S., Mardiono, I., \& Yanuarso, H. D. (2020). Analisis Beban Kerja Mental Mahasiswa saat Perkuliahan Online Synchronous dan Asynchronous Menggunakan Metode Rating Scale Mental Effort. OPSI, 13(1), 49-55.

Djaja, S. (2017). Harapan Dan Tantangan Guru Pembelajar Moda Daring. JURNAL PENDIDIKAN EKONOMI: Jurnal Ilmiah Ilmu Pendidikan, Ilmu Ekonomi Dan Ilmu Sosial, 10(2).

Ernes, Y. (2020). 213 Siswa Ngadu ke KPAI Selama Belajar di Rumah, Ada soal "Tugas Maha Berat." Https://News.Detik.Com/Berita/d-4975072/213-Siswa-Ngadu-Ke-Kpai-SelamaBelajar-Di-Rumah-Ada-Soal-Tugas-Maha-Berat.

Goldstein, J. M. (2018). Using the Behavior Assessment System for Children-to Aid in the Treatment of Children in the Child Welfare System. Kean University.

Hinduja, S., \& Patchin, J. W. (2017). Cultivating youth resilience to prevent bullying and cyberbullying victimization. Child Abuse \& Neglect, 73, 51-62.

Hiranrithikorn, P. (2019). Advantages and Disadvantages of Online Learning. In 
INTERNATIONAL ACADEMIC MULTIDISCIPLINARY RESEARCH CONFERENCE IN BERLIN 2019 (pp. 14-17).

Hoult, R., Peel, M., \& Duffield, C. (2020). Lessons from Flipping Subjects in Engineering: Effectiveness of Student Learning in a Flipped Environment at the University Level. Journal of Civil Engineering Education, 147(1), 4020012.

Jordan, R. K., Shah, S. S., Desai, H., Tripi, J., Mitchell, A., \& Worth, R. G. (2020). Variation of stress levels, burnout, and resilience throughout the academic year in first-year medical students. Plos One, 15(10), e0240667.

Muhammad, H., Murtinugraha, R. E., \& Musalamah, S. (2020). Pengembangan Media Pembelajaran E-Learning Berbasis Moodle Pada Mata Kuliah Metodologi Penelitian. Jurnal Pensil: Pendidikan Teknik Sipil, 9(1), 54-60.

Mustika, S., \& Syukur, Y. (2019). Penyesuaian Diri Wanita Menopause dan Implikasinya dalam Pelayanan BK. E-Journal Pembelajaran Inovasi, Jurnal Ilmiah Pendidikan Dasar, 7(4).

Neufeld, A., Mossière, A., \& Malin, G. (2020). Basic psychological needs, more than mindfulness and resilience, relate to medical student stress: A case for shifting the focus of wellness curricula. Medical Teacher, 1-12.

Rahmatih, A. N., \& Fauzi, A. (2020). Persepsi Mahasiswa Calon Guru Sekolah Dasar dalam Menanggapi Perkuliahan secara Daring Selama Masa Covid-19. MODELING: Jurnal Program Studi PGMI, 7(2), 143-153.

Reivich, K., \& Shatté, A. (2002). The resilience factor: 7 essential skills for overcoming life's inevitable obstacles. Broadway books.

Rusdiana, E., \& Nugroho, A. (2020). Respon Mahasiswa Pada Pembelajaran Daring Bagi Mahasiswa Mata Kuliah Pengantar Hukum Indonesia UNESA. Integralistik, 31(1), 1-12.

Saugi, W. (2018). The Effectiveness of E-Learning Using Edmodo at Islamic Higher Education (PTKI) in East Kalimantan. Southeast Asian Journal of Islamic Education, 1(1), 59-72.

Suherman, S., Dewi, M. P., \& Ahmad, D. (2019). Penggunaan Elearning Berbasis Android Pada Perkuliahan Aktuaria. In National Conference on Mathematics Education (Vol. 1, pp. 146-154).

Wargadinata, W., Maimunah, I., Febriani, S. R., \& Humaira, L. (2020). Mediated Arabic Language Learning for Higher Education in COVID-19 Situation. Izdihar: Journal of Arabic Language Teaching, Linguistics, and Literature, 3(1), 59-78.

Yuliani, M., Simarmata, J., Susanti, S. S., Mahawati, E., Sudra, R. I., Dwiyanto, H., ... Yuniwati, I. (2020). Pembelajaran Daring untuk Pendidikan: Teori dan Penerapan. Yayasan Kita Menulis. 
